\title{
SPOPOLNJEVANJE IZOBRAŽEVALCEV JE NAŠA SKUPNA SKRB
}

Sodobna družba preživlja krizo in pri tem se soočamo tudi z izzivi globalizacije, hitrim tehnološkim razvojem, klimatskimi spremembami in demografskimi premiki. Prav čas krize pa naj bi bil tudi čas za pospešen razvoj, kjer ima izobraževanje ključno vlogo. Naša prihodnost je družba, ki temelji na znanju, zato potrebuje ustvarjalne in inovativne posameznike in skupine.

Naloga vseh, ki delamo na področju izobra ževanja odraslih, je tudi spodbujanje iskanja novih pristopov $k$ učenju in izobraževanju, pridobivanje znanja in urjenje veščin ter ustvarjanje takih razmer za učenje in izobraževanje, bodo prijazne do udeležencev bodo prijazne do w we tencev tako vormalnem kot neformalnem izobraževanju. Večina znanja, ki danes nastaja znotraj izobraževalnih organizacij in podjetij, je rezultat dolgoletnih prizadevanj različnih strokovnjakov. Na področju izobraževanja odraslih sestavljajo izobraževalci odraslih skupino strokovnjakov, ki opravlja številne in predusem selo ramjotike ni opravja

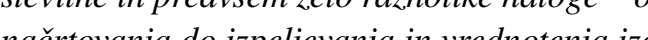
načrtowa pra do izpeljevanja in wrednotenja izobraževanja ter stevilhe podporne in druge dejavnosti, s katerimi spodbujajo in omogočajo, da se odrasli lahko učijo.

S študijo, ki smo jo v letu 2008 opravili na Andragoškem centru Slovenije, ${ }^{I}$ smo ugotovili, da jemo z zelo različnimi polliciuni profili, saj

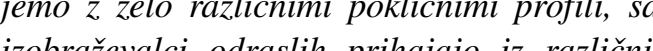
izobraževalci odrusth prih juzo rični študijskih smeri, na katerih si pridobijo bolj ali manj ustrezna znanja s tega področja. Vključujejo se strokovnjaki z različnimi stopnjami

UVODNIK dosežene izobrazbe, različnimi delovnimi izkušnjami in ne nazadnje tudi različnimi znanji. ki so si jih pridobili s strokovnim usposabljanjem in spopolnjevanjem.

Posledica tega je, da se na področju izobrǎ̌vanja orraslih oblikujejo vse bolj specifične zloge izobraževarev odraslih ki nastajajo vloge izobražcacten odraslin, hi nastajajo nje značilnosti in tudi zahtevnosti vlog izobra ževalcev odraslih vplivajo potrebe različnih ciljnih skupin udeležencev, različna učna okolja, učne oblike, ki jih izvajajo izobraževalci odraslih, pa tudi različne funkcije oz. naloge znotraj izobraževalnih organizacij - npr. strokovne, poslovodske in podobno.

Za področje izobraževanja odraslih je vloga izobraževalcev odraslih ključnega pomena, saj skrbijo za to, da si udeleženci pridobijo ustrezno znanje, kompetence in veščine. Da bodo lahko izpolnili svoje poslanstvo, morajo biti strokomjaki na siojem primarnem strokowem področje strokowo pa morajo biti podk področju stroks tudi na drugih podrocj in, pomenbih za kakovostno oblikovanje in izpeljevanje učnega procesa v izobraževanju odraslih, kar z drugimi besedami pomeni, da se morajo nenehno izobraževati, usposabljati in spopolnjevat.

$V$ iskanju odgovorov na različna vprašanja, $k i$ orajajo, smo v tem letu skladno s smernicami Akcijskega načrta za izobraževanje odraslih: Za učenje je vedno pravi čas in predvsem z željo, da izmenjamo mnenja strokovnjakov z različnih področij, na Andrago- 
škem centru Slovenije organizirali več poglobljenih strokovnih razprav. In prav prva med njimi je bila namenjena osvetlitvi problema usposobljenosti izobraževalcev odraslih. Razprave se je udeležilo 22 uglednih strokovnjako $s$ fakultet, ministrstev, javnih zavodov, društev in gospodarstva, ki se pri svojem delu tako ali drugače vsi stečujejo s področjem izobračevjia odraslih. Z uvodnim prispevkom sta med drugim sodelovali tudi dr. Barica Marencic Požarnik in dr. Sabina Jelenc Krašovec s Filozofske fakultete.

Dr. Barica Marentič Požarnik je poudarila, da je izobraževanje odraslih zelo zahtevno področje, na katerem lahko samo z izobraževanjem, učenjem in primernim odnosom pripomoremo $k$ razvoju strokovnjaka, v našem primeru izobraževalca odraslih.

Po njenem mnenju je prav odnos pedagoga ali andragoga do učečega se posameznika tisti temeljni vir, ki nam na nezavedni ravni zagotavlja, da se bo posameznik lahko usperno razvijal. Zato bi moral bin izobrazevevalec odraslih oseba, ki je empatična, sposobna povezovati teorijo, prakso in lastno refleksijo, ima stalno željo po samoizobraževanju, izmenjavi izkušnj, samovrednotenju, hkrati pa je dovolj kolegionalna, predvsem $v$ smislu prenosa znanja. Da bi lahko vse to dosegli, naj bi izobraževalci Da bi lahko poske to dosegli, naj bi izobrazevalci ker bodo le tako lahko uspešno pomagali posameznikom premagovati ovire, s katerimi se tina
svoji izobraževalni poti pogosto srečujejo.

Po prepričanju dr. Sabine Jelenc Krašovec potrebuje današnja družba izobraževalca odraslih, ki bo znal razmišljati kritično in na probleme gledati širše, potrebuje izobraževalca in intelektualca, ki si bo znal o vsem, kar se dogaja, ustvariti lastno mnenje. Da bomo to dosegli, bo treba najprej sistemsko urediti področje izobraževanja odraslih, ki je zdaj izrazito kadrovsko podhranjeno in na vseh področjih, od financiranja do zakonodaje in delovanja javne rreže za izobraževanje odraslih, izrazito neurejeno.

Da je področje izobraževanja odraslih sistemsko neurejeno in s tem marginalizirano, se je $v$ strokovni razpravi strinjala tudi Ema Perme, vodja sektorja izobraževanja odraslih na ministrstvu za šolstvo in šport. Po njenem mnenju so spremembe nujne, prvi korak, ki ga bo naredilo njihovo ministrstvo, pa je, da bo poskušalo z bolj odprto zakonodajo področju izobraževanja odraslih zagotoviti ustreznejši položaj.

Tudi evropska raziskava na področju izobraževanja odraslih ${ }^{2}$ je pokazala, da so učitelji draslih »marginalna skupina «, pogosto opravljajo delo za določen čas, odrasle pogosto izobražujejo kadri, ki nimajo ustreznih andragoških znanj, zato je potreben razmislek, ali z odraslimi res lahko dela vsak, ki si to želi.

Marginalnost se kaže predvsem $v$ neustrezni umeščnosti področja v celoten družbeni sni žbeni sisem, saj je izobraževanje odraslih prepogosto odvisno od trenutne politike in usmeritve gospodarstva. In ko razmišljamo o njihovi udeleženosti v izobraževanju, ugotovimo, da so prav izobraževalci odraslih najbolj podhranjena skupina izobraževalcev.

Tudi z našo študijo v letu 2008 smo ugotovili, da delo izobraževalcev odraslih opravljajo različni strokovnjaki, ki pri svojem strokovnem študiju, pa tudi pozneje, povečini niso bili deležni obsežnejšega in sistematičnega pedagoško-andragoškega izobraževanja ali spopolnjevanja. Se posebno to velja za številne izobraževal$c e$, ki delujejo na področju neformalnega in splošnega izobraževanja. Slabo skrb za izobraževanje izobraževalcev odraslih lahko razumemo le kot enega od odsevov slabe skrbi za področje izobraževanja odraslih nasploh, zavedati pa se moramo, da so prav izobraževalci odraslih tisti, ki lahko s svojim delovanjem in zavzemanjem za udeležence v izobraževanju odraslih to stanje tudi presežejo.

Zato postaja stalno strokovno spopolnjevanje vse pomembnejsi dejavnik strokovnega razvoja slehernega izobraževalca odraslih, ki mu Andragoški center Slovenije že od ustanovitve naprej posveča posebno pozornost. Rezultat študije, ki smo jo opravili v letu 2008, so pokazali, da so naši programi usposabljanj (gre za programe neformalnega izobraževanja, razvojne programe, programe andragoškega spopolnjevanja, za ranljive skupine), ki jih namenjamo različnim ciljnim skupinam odraslih, zanje ustrezni, seveda pa jih je treba stalno nadgrajevati in dopolnjevati.

Ob programih, ki smo jih razvijali za odrasle, smo vzporedno vedno poskrbeli tudi za razvoj programov spopolnjevanja izobraževalcev odraslih (učiteljev odraslih), ki $v$ teh programih delujejo. Zavedamo se namreč, da je kakovost dela izobraževalcev odraslih eden najpomembrikov uspeha ki se, gledanod ročno, bogato obrestuje.

Zavedamo se tudi, da je za Slovenijo, če želi narediti razvojni preboj na področju izobraževanja odraslih, poleg raziskovalnega in razvojnega dela, ki lahko omogoči nove razvojne projekte, odločilnega pomena, ali bodo izvajalci teh razvojnih projektov dobro usposobljeni 3 njihovo uresnic njihovim sistematicnim in kakowostmin spopolnjevanjem. Da bi pri svojem delu lahko uspešno uresničevali cilje, ki jih narekuje načelo vseživljenjskega učenja, morajo biti pripravljeni na lastno vseživljenjsko učenje.

Brez zadržkov lahko torej pritrdimo splošneти spoznanju, da je treba pri uveljavljanju na znanju temelječe družbe posebno skrb posvetit stalnemu spopolnjevanju izobraževalcev odraslih. Zaradi različnih vlog, ki jih ti opravljajo

je ključnega pomena, da si, poleg aktualnega znanja na področju posamezne stroke, pridobijo tudi znanje s področja poznavanja in proučevanja značilnosti ciljnih skupin odraslih, znanje o strategijah načrtovanja in izpeljave izobraže vanja, o temeljnih značilnostih dela z odraslimi, psihologiji učenja, motivaciji za učenje in izobraževanje, znanje za upoštevanje prejšnjega znanja in izkusenj odraslihv izobraževalnem procesu, za vrednotenje znanja, vzpostavljanje primernega učnega okolja (ob upoštevanju razlik med posamezniki in skupinami), znanje za svetovalno, raziskovalno in razvojno delo poznavanje novih metod učenja in poučevanja ter številne druge vsebine, odvisno od potreb in interesov vsakega posameznega zaposlenega izobraževanju odraslih.

$V$ že omenjeni študiji so vprašani kot najpomembnejše vsebine, $k i$ jih potrebujejo pri svojem delu, navajali: sodobne učne metode in oblike izobraževanja odraslih, svetovalne in druge kompetence pri izobraževanju ranljivih družbenih skupin, aktualne vsebine, ki so povezane s spreminjanjem zakonodaje in uvajanjenovih strokow ih rexitev, kamor lahko unstimo prilagajanje izobraževanja odraslim, uvajanje elektronskega učenja, ugotavljanje in potrjevanje predhodno pridobljenega znanja, sodelovanje pri novih projektih in podobno. Izrazili so tudi potrebo po nadaljnjem zagotavljanju usposabljanj in spopolnjevanj v podporo razvojnim projektom (projekti kakovosti, pismenosti, središca za samostojno učenje, svetoulna sedičca ISIO, PUM). С in izvajalcem mnogih programov za izobraževanje učiteljev in mentorjev odraslih to težko razumeti, pa moramo vendarle ugotoviti, da je bilo izobraževanju in spopolnjevanju izobraževalcev odraslih namenjene premalo pozornost predvsem pa premalo sredstev, da bi na tem področju lahko uresničevali vse zastavljene cilje.

Zato je nujno, da se začnemo izobraževalci odraslih med seboj še bolj povezovati - tako tisti, ki izobražujemo odrasle v formalnih izobraže- 
valnih programih, kot tisti, ki izobražujemo v programih neformalnega izobraževanja in da ne delujemo kot »čebelarsko društvo«, kot je v strokovni razpravi to poimenovala Sonja Klemenčič z Andragoškega centra Slovenije.

Vse nas, ki delujemo na področju izobraževanja odraslih, torej čaka še veliko dela. Le če bo spopolnjevanje izobraževalcev postalo naša skupna skrb, bodo prišli tudi rezultati in uspehi. In še na nekaj ne smemo pozabiti, namreč, da razvitost izobraževalnega sistema države omogočajo dobro izobraženi in usposobljeni izobraževalci odraslih.

Mag. Zdenka Birman Forjanič
${ }^{1}$ Prikaz dosežkov in razvojnih izzivov izobraževalne dejavnosti Andragoškega centra Slovenije, Izhodišca za oblikovanje novega koncepta andragoskega spopolnjevanja, (http://izobrazevanijeacs.si/dokumenti/razvojno_delo/PRIKAZ_DOSEZKOV_IN_RAZVOJNIH_IZZIVOV_IZOBRAZEVALNE_DEJAVNOSTI_ACS.pdff.

ALPINE - Adult Learning Professions in Europe - A study of the current situation, trends and issues, 2008.

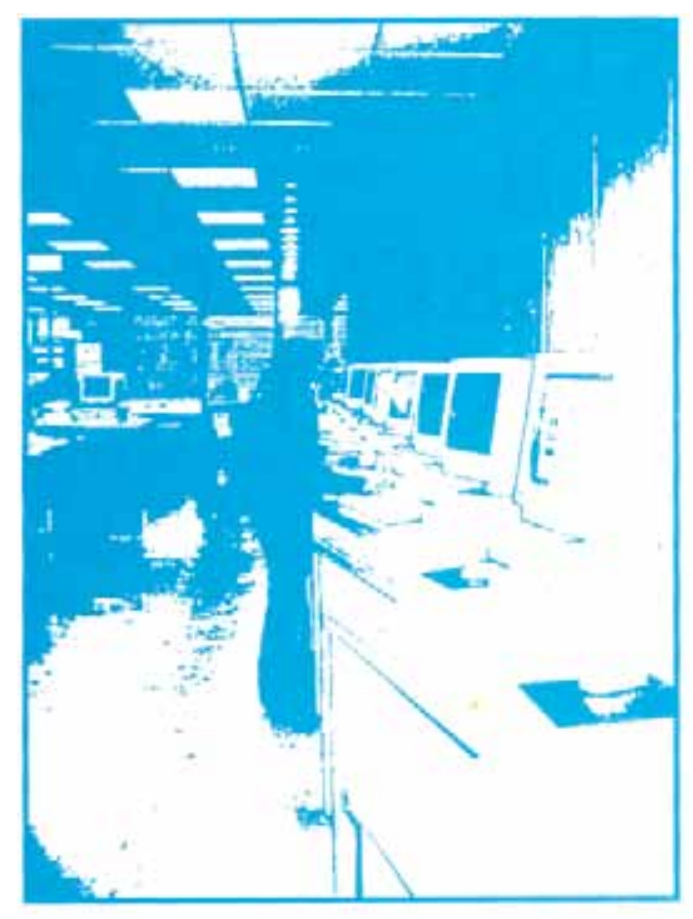

\section{ZNANOST RAZKRIVA}

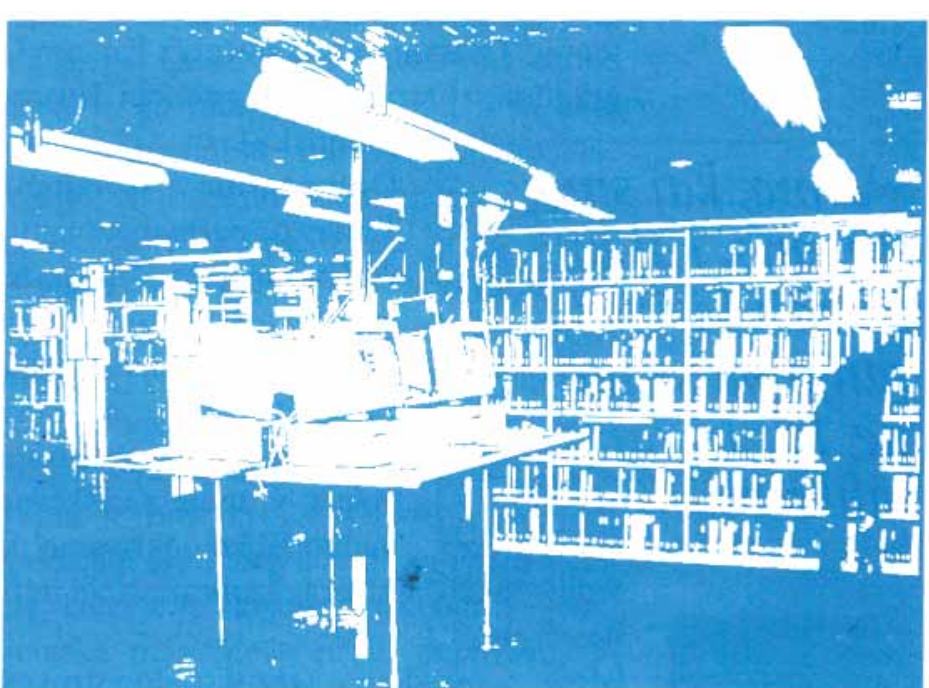

